\title{
MEDIATION AND CONCILIATION AS APPROPRIATE METHODS OF CONFLICT RESOLUTION (MASCS) FOR THE PROMOTION OF ACCESS TO JUSTICE AND CULTURE OF PEACE
}

\author{
Vanessa Miranda ${ }^{1}, \&$ Leila Salles ${ }^{2}$ \\ ${ }^{1}$ Imperatriz of College - Facimp Wyden (Brazil) \\ ${ }^{2}$ Unialfa-Universit Center Alves Farias (Brazil)
}

\begin{abstract}
In this study, we analyze mediation and conciliation as appropriate methods of resolving conflicts for the realization of access to justice and the construction of a culture of peace. The interest in this study arose from the observance of the social mobilization and the Brazilian public power in implementing mechanisms for resolving appropriate, effective and efficient conflicts. In the year 2013, the Justice in Numbers Report, of 2015, indicated the total number of 95.1 million processes In the Brazilian courts, and this number, according to projections, can reach the brand of 114.5 million in 2020. Thus, the Judiciary instituted the National Judicial Policy for appropriate treatment of conflicts (Resolution No. 125/2010, BRAZIL, 2010) as a way to consolidate a permanent policy of incentive and improvement of the mechanisms Autocompositive. The Problem of this research is to ask how mediation and conciliation as conflict resolution techniques have been employed in the Brazilian legal system and to investigate how these techniques have been constituted and effective as a public policy for the Access to justice. To this end, a bibliographic research is carried out on the conceptions of conflict, mediations and Appropriate Methods of conflict Resolution and analyzed how these guidelines have permeated the Brazilian public policies of access to justice and the promotion of the culture of peace. The Judicial Centers for Conflict Resolution (CEJUSCS), which are units of self-composition in the judicial system, were also investigated with the objective of knowing the structure, organization, functioning and implementation of these centers. They were also examined as mediators and conciliators have been trained to act in the judiciary. $\mathrm{O}$ theoretical framework is based on Cappelletti and Garth and Kazuo Watanabe, as regards access to justice and fair legal order in search of a socially just and equitable society. The analyses indicated that mediation and conciliation are instruments that were incorporated into the Brazilian Judiciary for the realization of access to justice and social pacification and because it is understood that the judicial function is not restricted to a decision imposed by the judge to the extent that it also seeks to promote mechanisms that allow access to justice, by means of non-heteronomous.
\end{abstract}

Keywords: Conflict, mediation, conciliation, justice.

\section{Introduction}

This research examines the methods employees for conflict resolution, as the mediation and the conciliation, as a means of access to justice and the promotion of the culture of peace.

The interest by this study came of research conducted by the National Council of Justice (CNJ) in 2013, which culminated in the publication the "Report Justice in Numbers 2015". The survey carried out for this report indicated that in the year 2013 there were 95.1 million processes In the Brazilian Judicial proceedings. According to projections made by the CNJ, this number can reach the mark of 114.5 million in 2020. Thus, the Judiciary instituted the National Judicial Policy for appropriate treatment of conflicts (Resolution $N^{\circ} 125 / 2010$, BRAZIL, 2010) As a means of consolidating a permanent policy of incentive and improvement of consensual dispute settlement mechanisms, considering that the right of access to justice is to have access to a fair legal order in accordance with CRFB/88. The action of the Judiciary by installing the mediation and conciliation of conflicts in its units of self-composition called the Judicial Centers for Conflict Resolution and Citizenship (CEJUSCS) contributes to the democratic process by promoting access to justice In a broad, effective, democratic manner and co-participated as a fundamental element of sustainable human development.

The problematic main of this research is to inquire as a mediation and conciliation of conflicts have been employed in the Brazilian legal system seeking to investigate how these techniques have constituted and become effective while a public policy for access to justice. Thus, the present work aims 
to analyze mediation and conciliation as mechanisms of conflict resolution in the implementation of access to justice in the Brazilian legal for the construction of peace culture.

The importance of access to justice is highlighted by Cappelletti and Garth (1988, p. 11-12) when they say that: "First, the system must also be accessible to all; Second, it should produce results that are individual and socially fair". The authors complement these statements by saying that "the access to justice can be regarded as a fundamental requirement - the most basic human rights - of a modern and egalitarian legal system that intends to guarantee, and not only to proclaim the right of all”. Thus, the present research aims to understand the contribution of mediation and conciliation for the realization of access to justice and the promotion of the culture of peace.

\section{Conflict}

To Chrispino (2007, p. 15), the conflict is: "every divergent opinion or different way of seeing or interpreting any event". Conflict is part of society, there is visto that, we live with plurality of people with interpretations, opinions and ways of looking at situations in a different way. So, as you say Chisprino, (2007, p. 17): "In a community that is trained to inhibit the conflict, this is seen as something bad, an anomaly", while something to be suppressed. And according to Chrispino (2007), Vasconcelos (2015) and Tartuce (2015), conflict is understood as a crisis, as a dispute. However, because it is part of society and because it is derived from different human perceptions, the conflict it is a phenomenon that should not be understood in a negative or polarised way. The negative perception of the conflict demonstrates the "difficulty in dealing with the conflict, because of our inability to identify the circumstances that derive from the conflict or to be reduned in it" (CHRISPRINO, 2007, p. 15). So the conflict comes to be regarded as something inevitable but also positive in relation to social relations.

By losing the notion that equals conflict to something negative, it is possible to perceive it as a phenomenon that is likely to be conducted, that is, that does not necessarily lead to violence. Second Galtung (2005) Intervention Situation of conflict may enable them to not trigger Relations Violent. The solution of the conflict for the parties in dispute would entail a process of building peace. The Peace considered by Galtung (2003), is a positive relationship between the parties, a union, a communion. The condition for peace is mutual respect, dignity, equality, reciprocity - all in the three spheres: spirit, mind and body; Political culture and economics.

The Culture of Peace movement began in 1999, the United Nations Educational, Scientific and Cultural Organization (UNESCO). The purpose of this movement was to prevent conflicts or situations that could threaten peace and security - such as disrespect for human rights, discrimination and intolerance, social exclusion, extreme poverty and environmental degradation - using the main tools to raise awareness, education and prevention. It is Based on the principles of tolerance, solidarity, respect for life, individual rights and pluralism. Culture of Peace, as defined by Chrispino and Dusi (2008 p. 604), Implies "Um set of values, attitudes, traditions, behaviors and lifestyles based on full respect for life and the promotion of human rights and fundamental freedoms, fostering peace between people, groups and nations" being able, including, be a political strategy for the transformation of the social reality.

Since 1995, the debates on education for peace have been intensified, considering respect for differences, overcoming situations of exclusion, solidarity between peoples and dialogue as an instrument of negotiation. These discussions have mobilized governments, civil society, ONGs and educators (VON, 2003, p. 9). In This Way, instruments have been sought in order to manage conflicts so that they are dealt with in a way that does not trigger acts of violence. Among These mechanisms are the Mediation and conciliation as conflict resolution techniques.

\section{Mediation and conciliation as appropriate methods of conflict resolution}

Castilho apud Tartuce (2015, p. 15), highlights three possible solutions to a conflict situation: self-guardianship, hetero-composition and self-composition. The self-guardianship does not behave, because the individual solves the conflict by his unilateral strength, acting without the intervention of another, in order that his interest preponder on the other, seeks to gain advantage over the other. Self-guardianship means the use of unilateral force, there is no external care, but rather the use of the power of one over the other.

The main difference between self-composition and hetero-composition, relates to the model called adversarial (jurisdiction and arbitration) characteristic of the hetero-composition, where there are winners and losers. In the self-composition carried out by means of trading "The solution seeks the gain of all parties, that is, observance of the interests of all involved". (SPENGLER, 2016, p. 75).

Mediation and conciliation are mechanisms of self-composition, called Tartuce (2015, p. 47), as "facilitated bilateral self-composition". According to Didier (2015, p. 165) "this modality of composition of conflicts occurs through the spontaneous consent of one of the contenders in sacrificing self-interest, in whole or in part, in favor of others interests." 
Conciliation is a technical Autocompositive Facilitated conflict management, which may occur judicial or extrajudicial, conducted by an impartial third party suggesting possible solutions to the parties, assisting in the administration of the conflict. Right a method used in simpler, or restricted conflicts, in which the facilitator can adopt a more active, but neutral and impartial position. It Is a brief consensual process, which seeks an effective social harmonization and restoration, within the possible limits, of the social relationship of the parties. (BRAZIL, 2015). To Spengler (2016, p. 75), the conciliation "aims to reach a neutral agreement voluntarily and has the participation of a third-conciliator - who intervenes and can, Including, suggest proposals for the purpose of directing the discussion. "

Mediation is a mechanism of conflict resolution imported from the North American model of the Multiport Court, in which the third, Impartial and capacitated, it approximates the parties to a dialogue, conducting communication, without giving suggestions, so that the parties themselves reach the solution of their controversy, whose nature is more complex and the relationship between the parties has a continuative bond. Therefore, mediation is the appropriate method for restoring and strengthening the bonds between the parties, who have a continued relationship (Sales, 2018). Mediation is the most suitable technique. When conflicts are of a family, affective, neighborhood order, in which the parties have a relationship that can last for years, or the life all, and the financial restoration is insufficient to end the conflict.

Conciliation and mediation as conflict resolution techniques are considered important instruments of social pacification. Conflicts are objects of action of the judicial system, since the State, in its judicial function, the function is to resolve the conflicts. The modality of solution used by the judiciary was predominantly the hetero-composition, however, it has been perceived the importance of the methods Autocompositive. In this way, the mediation and conciliation were adopted as public policies for access to justice, because it is understood that they are social harmonization techniques, contributing with and effective results of existing conflicts.

\section{Conciliation and mediation as public policies for access to justice and promotion of the culture of peace}

A Conciliation and mediation are, as we have already pointed out, "public policies aimed at access to justice" (Spengler, 2016, p. 70).

Bucci (Apud FONTE, 2015, p. 49) defines public policies as "government action programs for achieving determined objectives in a certain time space". To Secchi (2015, p. 11), public policies, is "one abstract concept that materializes through varied instruments ... take form of public programs, projects, laws, advertising campaigns, political clarifications, technological and organisational innovations, governmental subsidies, administrative routines, judicial decisions, coordinated actions of a network of Actors, direct public spending, formal and informal contracts with Stakeholders, among others".

A Constitution of the Federative Republic of Brazil, that establishes democracy in Brazil and ensures fundamental rights, in his preamble already reveals commitment with the peaceful settlement of controversies in domestic and international orders. In its normative body it brings several devices reaffirming as fundamental rights, o due to legal process, the incompetence of jurisdiction, the comprehensive and free legal assistance, a reasonable duration of the process, among other the that reveal the concern of the constituent with access to justice and its effectivity.

The mechanisms that effect access to justice are as important as the right to fair and equitable legal order. Cappelletti and Garth $(1988$, p. 8$)$ clarify that access to justice "serves to determine two basic purposes of the legal system - the system by which people can claim their rights and/or resolve their disputes under the auspices of the State." Access to justice has the purpose not only the right to claim and resort to the Judiciary to obtain a definitive answer (jurisdiction), but especially the access to a fair legal order: the right of protection and guarantee to the entire order of rights and values protected by the legal framework.

Access to justice is right to have rights. Among them in a broad, fair and egalitarian manner, mechanisms capable of resolving conflicts. As they say Mingati and Ricci (apud Grinover, 2007, p. 8): "the access to justice is a broad right to obtain the fair solution to the conflicts of interest" and "more than a mere instrument of jurisdiction, applicator of legal norms" is "an instrument capable of producing decisions according to an order of values identified in the legal". Thus, access to justice "is the most basic human right, among individual and social rights, whose mechanisms for its effectivation constitute the meaning of the right, being fundamental requirement to ensure a modern and egalitarian legal system." (CAPPELLETTI, GARTH, 1988, p. 11).

The implementation of these public policies Mediation and conciliation in 2013 with the publication of the Report Justice in Numbers 2015. Second Grinover (2007, p. 2) "soon was perceived, but That the State does not would be able to direct all the mass of disputes brought to the courts. And again the interest for the non-jurisdictional modalities of conflict resolution, treated as alternative means of social pacification", was reborn provided that the mechanisms for such pacification are efficient and fair. Continuing, the author states that "the perception that the State has failed in its peacemaking mission, 
which it tries to accomplish through jurisdiction and through the forms of the process" no the extent that the sentence authoritative the judge does not pacify the parties, be imposed, for as it says "there will be a part - and often the two - dissatisfied with the decision of the judge and recalcitrant in its fulfillment. On the other hand, the formalities of the procedure - the necessary limit to ensure their guarantees - require time, and time is the enemy of the pacifying function". (GRINOVER, 2007, p. 2). Therefore, one of the aspects used to overcome the difficulties faced by the Judiciary, in the sense of social peacemaker, was the insertion of mediation and conciliation.

As Sales and Chaves (2014) the results obtained by mediation and conciliation mobilized the Judiciary in the institution, regulation and organisation of these practices. The growing practice of mediation and conciliation across the country demonstrated the feasibility of these mechanisms to achieve social pacification through the solution and prevention of conflicts and for facilitating the access to justice contributing to a fair legal order. So much is that the National Council of Justice, attentive to these the results instituted a public policy that objective organize and standardize services with the Judiciary. (SALES and CHAVES, 2014, p. 267).

This policy provoked a mobilisation of the whole society and the Judiciary to find solutions to provide citizens with the fundamental right of access to justice, with regard to the appropriate, swift, fair and effective treatment of conflicts.

In This way, these instruments have proved to be of paramount importance at the global level in promoting the culture of peace. They are mechanisms that can be used without territorial obstacles or bureaucracies. Learning to solve conflicts through mediation and conciliation means the possibility of peaceful coexistence, not without conflict, but with effective, less costly and more accessible instruments.

\section{Final considerations}

The mediation and conciliation are appropriate methods of resolving conflicts incorporated in the structure of self-composition of the Judiciary, by Resolution $n^{\circ} .125 / 2010 / \mathrm{CNJ}$, as a way to broaden the forms of treatment of conflict in society.

The Mediation and conciliation, as mechanisms of self-composition, were adopted as public policies for access to justice, contributing to the comprehensive ness and more effective results of existing conflicts and strategies incorporated by the Judiciary to promote the Culture of Peace, since they are mechanisms with the ability to encourage democratic participation, cooperation, mutual respect, equality and the construction of conflict resolution, developing skills to converge interests, opposing opinions. They are mechanisms that promote access to justice, in a broad sense, that is, not only access to the Judiciary, but to the right to fair and equal legal order.

And, so we believe, they must be public policy to be encouraged.

\section{References}

A proposal for public policy modeling to reduce school violence and promote the Culture of Peace. Test: Aval. Pol. públ. Educ., 10 2008, vol. 16, No. 61, p. 597-624. 2018.

A proposal for public policy modeling to reduce school violence and promote the culture of peace. Test: Evaluation of public policies in education, V. 6, N. 61, P. 597-624, Oct./dez. 2008.

Brazil. (Constitution). Constitution of the Federative Republic of Brazil of 1988. Brasilia, October 5, 1988. Available at: http://www.planalto.gov.br/ccivil_03/constituicao/ConstituicaoCompilado.htm >. Access on: 28 Jan. 2017.

Campos, Mauro; Garth, Bryant. Access to Justice. Letra e video Ellen Gracie Northfleet. Porto Alegre, Fabris, 1988.

Chrispino Alvaro; Dusi, Miriam Lucia Herrera Masotti. A proposal for public policy modeling to reduce school violence and promote the Culture of Peace. Test: Aval. Pol. públ. Educ., 10 2008, vol. 16, No. 61, p. 597-624. Available from: < http://www.scielo.br/Pdf/ensaio/v16n61/v16n61a07.pdf. > Access on March 23. 2017.

Chrispino Alvaro; Santos, T. Conception. Teaching Policy for the prevention of violence: teaching techniques that can contribute to the reduction of school violence. TestEndorsement. Pol. Facilit. Educ., Mar 2011, vol. 19, No. 70, p. 57-80. Available from: < http://www.scielo.org/cgibin/wxis.exe/applications/scieloorg/iah/?IsisScript=iah/iah.xis\&base=article\%5Edart.org\&nextAction=lnk\&lang=p\&indexSearch= \&exprSearch=MEDIACAO\%20DE\%20CONFLITO\%20ESCOLAR. > Access on March 23. 2017.

Didier JR, Freddie. Civil Procedural Law Course: Introduction to Civil Procedural Law, General Part and knowledge process. 17. Ed. - Salvador: ED. JUS PODIVM, 2015.

Dusi, M. L. M.; Araújo, C.M. M; Neves, M.M.B.J. Culture of Peace and school psychology in the context of the educational institution, 2005, V. 9, N. 1, Campinas. Available from: 
<http://www.scielo.br/scielo.php?script=sci_arttext\&pid=S1413-85572005000100013. > Access on: March 23. 2017.

Galtung, Johan. Methods for terminating conflicts: Judicial proceedings to mediation. 2005, Mexico. Available at: 〈http://www.comitepaz.org.br>. Accessed on: Feb 13. 2017.

Grinover, Ada Pellegrini. Culture of conciliation in Brazil does not depend only on [periodic] laws. -São Paulo: Legal Adviser, 2015. - Accessed on: January 17, 2015: Vols. Available at: <http://www.conjur.com.br/2015-nov-27/culture-conciliation-not-depend-laws-ada-pellegrini.> Access on March 23. 2017.

Law No. 13,105, of March 16, 2015. Code of Civil Procedure. Brasilia, March 16, 2015. Law. Available at: <http://www.planalto.gov.br/ccivil_03/_ato2015-2018/2015/lei/113105.htm>. Access on: 08 Jan. 2018.

Law No. 13,140, of June 26, 2015. It has on mediation between individuals as a means of dispute settlement and the self-composition of conflicts within the public administration; Amends the Law no 9,469, of July 10, 1997, and the Decree no 70,235, of March 6, 1972; and Repeals $\S 2^{\circ}$ of art. $6^{\circ}$ of the Law no 9,469, of July 10, 1997. 2015. Law. Available at: <http://www.planalto.gov.br/ccivil_03/_ato2015-2018/2015/Lei/L13140.htm>. Access on: 29 Jan. 2018.

Morin, Edgar. Towards the inevitable abyss? 2001. Available at: < http://www.comitepaz.org.br>. Accessed on: Feb 12. 2017.

National Council of Justice-CNJ. Judicial Mediation Handbook, 6th Edition. (Brasília/DF: CNJ), 2016. Available <http://www.cnj.jus.br/files/conteudo/arquivo/2016/07/f247f5ce60df2774c59d6e2dddbfec54.pdf> Access on 23 Apr. 2017.

National Council of Justice-CNJ. Justice in Numbers. 2015. Available at: <http://www.cnj.jus.br/programas-e-acoes/politica-nacional-de-priorizacao-do-1-grau-dejurisdicao/dados-estatisticos-priorizacao.>. Access on March 23.2017.

National Council of Justice-CNJ. Resolution No. 125 of the CNJ. 2010. Available at: <http://www.cnj.jus.br/Search-Acts-adm? document= 2579. >. Access on March 23. 2017.

National Council of Justice-CNJ. Statistical Data. 2015. Available at: <http://www.cnj.jus.br/programase-acoes/politica-nacional-de-priorizacao-do-1-grau-de-jurisdicao/dados-estatisticos-priorizacao>. Access on March 23.2017.

Sales, Lilia Maia De Morais; CHAVES, Emmanuela Carvalho Cipriano. Mediation and judicial conciliation - The Importance of Training and its Challenges. 2014. Available at: <http://www.scielo.br/pdf/seq/n69/11.pdf. > Access on: March 03. 2017.

Secchi, Leonardo. Public Policies -Concepts, analysis schemes, practical cases. 2. ed. São Paulo: Cengage Learning, 2015.

Spengler, Fabiana Marion. Conflict Mediation -From theory to practice. -Porto Alegre: Lawyer's bookstore, 2016.

Tartuce, Fernanda. Mediation in civil conflicts. -2. Ed, see, Current. And Ampl. - Rio de Janeiro: Forensic; São Paulo: MétoFrom: 2015 in.

The inclearability of judicial control and a new modality of self-guardianship (single paragraphs of articles 249 and 251 of the Civil Code). Brazilian Journal of Constitutional Law - RBDC N. 10 - Jul./dez. 2007.

Three forms of violence, three forms of peace. Peace, war and Indo-European social formation. Critical Journal of social sciences 71, June 2005:63-75. Letra e video João Paulo Moreira. 2005.

Vasconcelos, Carlos Eduardo. Mediation of conflicts and restorative practices. 4. ed. View. Current. Ampl. Rio de Janeiro: Forensic; São Paulo: Method, 2015.

Von, Cristina. Culture of Peace: What Individuals, groups, schools and organizations can do for peace in the world. São Paulo: Petrópolis, 2003.

Watanabe. K. Mediation Modality CEJ Notebooks Series, 22 Society cannot be so dependent on the State to resolve conflicts. 2014. Available at: <http://www.conjur.com.br/2014-nov-09/interview-kazuowatanabe-lawyer-judge-retired-tj-sp.> Access on: Jul 21. 2017. Mediation Modality, CEJ Notebooks Series, 22 www.cahali.adv.br/arquivos/artigo-kazuo-watanabe- modality-frommediation.pdf. Access on 12/04/2018

What is a culture of peace and what os obstacles that separate us from it? 2003. Available at: <http://www.comitepaz.org.br.> Access on: Feb 12th. 2017.

World Powers are behind crises in Africa, 2006. São Paulo. Available from: <http://www.comitepaz.org.br.> Access on Feb 12. 2017. 